\title{
Local Wisdom and Social Dilemma Has Allergy Upon Worn Value, Proudly with Currently Values (Viewed from Social Anthropology Perspective for Orang Ocu)
}

DOI: https://doi.org/10.47175/rissj.v2i3.252

\section{| Syafrizal | \\ Lecturer of Kopertis Region I, Faculty of Social and Political Sciences, Universitas Muhammadiyah Sumatera Utara, Indonesia}

syafrizal@umsu.ac.id

\begin{abstract}
It is noted that local wisdom is considered as an adjustable thing, flexible so that in variously social element openly to discuss it out. The main topics to discuss is to correlate local wisdom phenomenon and also found a social dilemma might arise there, such as communal activities recorded public see allergic with any old values, having proudly with newly values, it is all viewed from social anthropology perspective. This research has been done in qualitative approach within a very long time duration period calculated in completing Doctoral program in study, still to do restudy (another research) only done them in a short time, it has already data previously reasonable, in this case to community of Ocu on Kabupaten Kampar Riau. Accordingly, a partly of the study is categorized as ethnography research due to the source of data originally from informants chosen purposively under consideration of appropriately quality, figurative value, or someone as considered someone with much knowledge about the topic is discussing to. This study has found own very high strategic values which things can be set as instrument for criticizing even in this case with own initiative to commence re-repairmen particularly to its cultural values holed by local people whose neglect own old cultural values available, unfortunately in highly obsession to receive newly cultural values at any time having not comfortable however with the living pattern and their character in daily life, thence emerging in what generally called lost cultural with local condition is well known with "aghokkan ujan dilangik, ayu dikulam babuangkan".
\end{abstract}

KEYWORDS

local wisdom; allergic; worn values.

\section{INTRODUCTION}

Local wisdom can be identified with the real picture of a community group through the variety of works they produce. One form of this work is in the form of a code of conduct which is then accepted as a shared value as a regulator of social relations (Syafrizal, 2017). In a wider context, local wisdom directly or indirectly has a relationship with the diversity aspects that exist in our country, Indonesia.

As a social reality, it is local wisdom that distinguishes one group from another, as well as showing its uniqueness as an ethnic group. For example, there is a social assessment, the Batak tribe is thick with openness, the Javanese are almost synonymous with refinement, the Madurese have high self-esteem, and the Chinese are known for their tenacity.

The phenomenon that shows such uniqueness is not only represented by a large ethnic group, but can be found even in a small ethnic group. Actually, the big and small ethnic 
dichotomy is not an absolute aspect to call an ethnic group. Put forward by Izikowitz, K. G (1963), what is more important than that is the real ability of a group to show that they have their own identity which can then be recognized and accepted by other groups.

Boundaries between various ethnic groups occur because of socio-cultural differences. These differences can be classified into three groups, including: 1) differences in the way they are expressed (language, attitudes and ethics and habits, 2) value systems, presumably due to social structures and views of the outside world, 3) self-knowledge, related to selfresponses. about which group a person belongs to, as well as the group's acceptance of him.

Another view, by Syafrizal (2004), although in a different context that regarding the existence of large and small groups, in addition to this situation as a real social reality, this situation is expected to have an impact as an affirmation for their group. It is in this context that ethnic perpetuation begins its adventure in the political aspect. Furthermore, local wisdom is formed and matured by various testing processes in the course of a group.

The process of proving that maturity then gives confidence to all members of the group that the value of wisdom they create and raises will provide goodness for the sustainability of their lives in the future. It is from this process that a more mature process begins, namely the traditional inheritance process, which is firmly held together and maintained together. There are many factors that make local wisdom and community culture in general lose their strength.

In addition to the community's inability to interpret creatively and contextually their local wisdom, other factors are the result of globalization, and the subjective interests of some community elites. The form of polarization of patterned social interactions, designed with various kinds of joint actions with community members, starting from the relationship between community members in interacting. Patterns of interpersonal relationships, and personal relationships with groups that take place in harmony and balance, will be able to produce a lot of energy in finding and agreeing on various shared values.

This description is in line with the view put forward by Jim Ife (2002), that local wisdom is the values that are created, developed and maintained in local communities and because of their ability to survive and become a way of life for the community. Local wisdom includes various mechanisms and ways to behave, behave and act as outlined in the social order.

The whole description above, it is not expected that serious problems will arise in the community where the value of local wisdom is produced, compared to the values of local wisdom brought from outside. Based on this statement and looking at the social reality that exists, especially in the practice of community life, in this case the ethnic Orang Ocu, there have been various forms of social behavior that show more appreciation for the practice of new values from outside than the old values which are then called with local wisdom.

The situation stated above is one of the social phenomena faced by various ethnic groups in this archipelago. This statement is based on the fast flow of scientific and technological progress, which if we compare it with efforts to maintain local cultural values, of course it is far from being roasted by fire. The development of science and technology is so persistent and targets all aspects of life by offering enjoyment, pleasure and satisfaction.

The presence of a facility full of beauty and satisfaction for technology users is a very difficult challenge to be penetrated by the strength of local cultural values. There will hardly be a formulation that is most likely to be chosen and implemented, unless all members of the community will jointly vote and do the same. This lack of choice makes 
indigenous groups invincible and in fact, they are often mired in situations that are not much different from the behavior of young people.

Giving more appreciation to new values, at the same time giving lower appreciation to local values that have existed for a long time, as well as being a social problem for Orang Ocu today, even this phenomenon is also being and will be found in community groups others in this country. The attitude of community groups can be read as a form of the process of starting to leave old values, at the same time starting the process of using new values, let alone being carried out recklessly without paying attention to the stages of social processes, including:

1) early detection as a selection effort to ensure that new values have been internalized in society, 2) a continuous deepening process to ensure the presence of new values in the long term will not make community members want to return to old values, 3 ) the process of leaping values from values old local wisdom to new values has been massively socialized.

If the three social processes stated above are not carried out properly, it is believed that they will result in various social problems. One social phenomenon that will be faced by the community is the occurrence of an imbalance in social relations which is projected to have an impact on other social aspects as a whole. The uncertainty of the reference to shared values, of course, will lead to multiple perceptions of the level of value that should be given to someone for their negligence.

For a variety of behavior that is categorized as positive, of course, it will not have serious implications in terms of its value, because something that is considered good will also be given a good value according to the social size in which the value and action are carried out. The description of the situation described above is actually a real situation that is currently happening in Orang Ocu. As a group with its own culture and value system, this group is considered to be risking their shared old value reference to be abandoned and has adopted a new pattern of behavior to accept new values as a common value reference, in a traditional Ocu expression "aghok kek ayu ujan tang langik, ayu dikulam bakoyongkan", which means expecting rainwater to fall from the sky, well water to be drained, is a relevant analogy to describe the current situation and condition of Ocu people, namely allergies to old values, pride in new values.

The value of the process contained in the above expression is and will continue in the various activities of this group. The tendency to practice new values and feel like a progressive, modern and slang society when it has abandoned the old ways that are still a reference for social behavior, especially the elderly. It is true that the current process is targeting Orang Ocu youth. Of course, gradually the use of new values carried out by young people will have a direct or indirect influence on members of society in general.

The problem to be explained in this study is the phenomenon of a shift in the value of local wisdom that can be observed as a social dilemma, in the form of community activities in the form of allergies to old values, pride in new values, viewed from the perspective of social anthropology. To clarify the problem, it can be seen in the following image: 


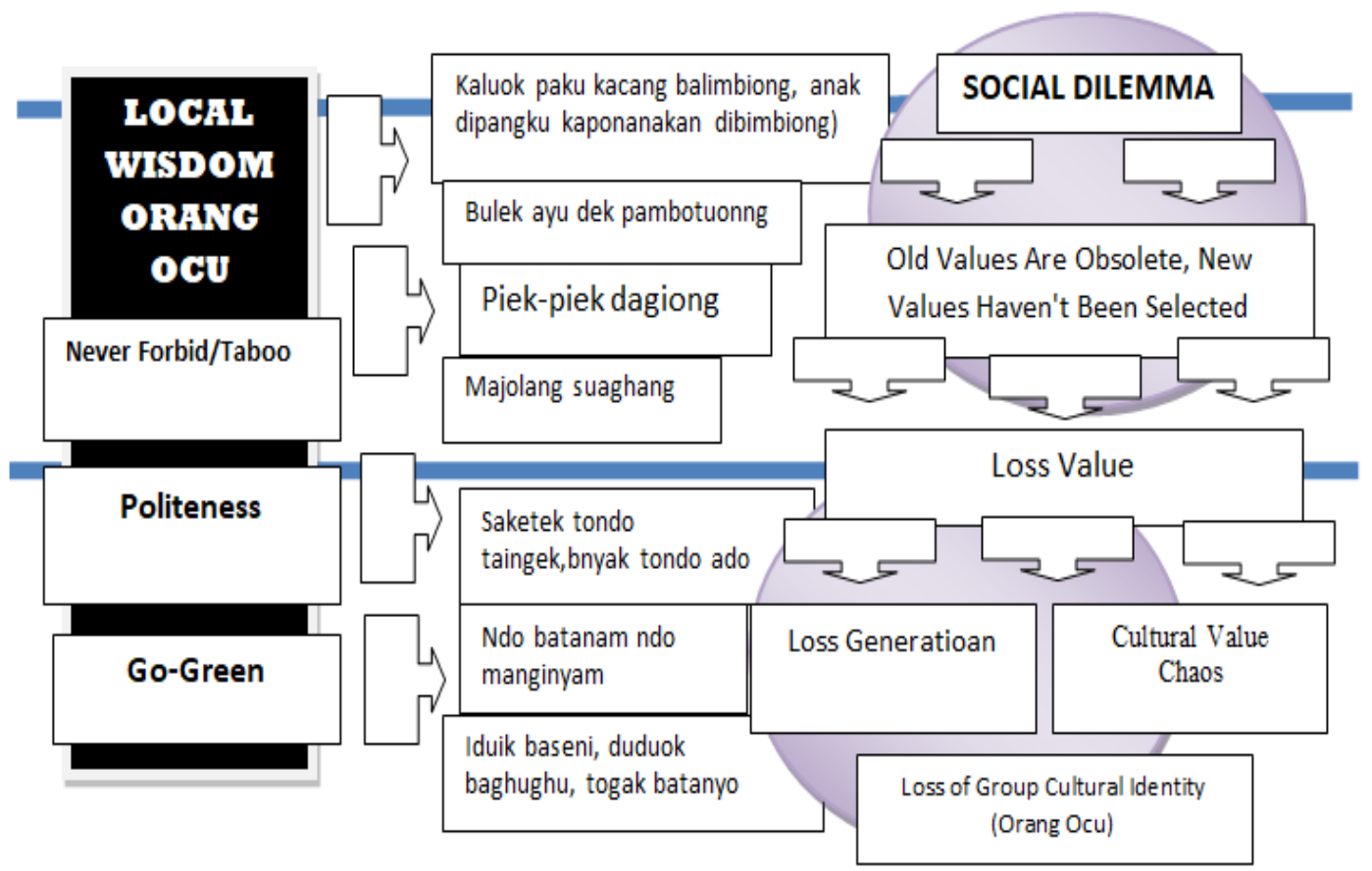

Figure 1. Flow of Thinking Local Wisdom and Social Dilemma Allergy to Old Values, Pride to New Values The Case of Orang Ocu Community

\section{LITERATURE REVIEW}

There are several main points described in this section, namely theoretical aspects that will help to explain the main issues studied, including:

\section{Local Wisdom General Concept}

In this section, various views on local wisdom will be described, especially those related to aspects of language, attitudes and ethics as well as habits. In the previous description, Izikowitz, K. G (1963), states that the boundaries between various ethnic groups occur because of socio-cultural differences, which manifest in the form of differences in the way they are expressed (language, attitudes and ethics and habits). Differences in the way of expression as a process of translating various behaviors through language, will result in a situation that can be called an attitude. The embodiment of attitudes that are in accordance with the reference of shared values will give meaning to the existence of ethical values in which various social values must be adhered to by all members of society.

The whole process like that will ultimately be measured by the value of appropriateness according to the size of social truth. The emergence of social truths that are appreciated and carried out jointly by members of the community, will eventually become a reference for shared behavior, and will even be inherited. As stated by Radcliffe-Brown, A, R (1952), that the process of behavior which is considered as the truth, is carried out together continuously, and carries on from generation to generation, can be said to be a habit. In the context of social life in general, the various values that must be adhered to are usually translated as forms of prohibited behavior and if violated or not adhered to, they will receive social sanctions.

The meaning of this kind of behavior in the social interactions of people in Indonesia is called the term abstinence, which is then also referred to by another term, namely taboo. In an article put forward by Radcliffe-Brown, A, R (1952), the term taboo comes from the Polynesian word "tabu" with an emphasis on the first syllable, namely abstinence. This 
word means prohibiting, prohibited or anything that is prohibited, such as an order to children not to do anything that can harm others, or to do something that their parents have forbidden. taboo words.

In the practice of Polynesian life, something that is taboo can be stated in two conditions, namely: first, someone who has made a mistake by doing something that has been taboo (forbidden) by society, such as touching a corpse (a deceased person) so that the person himself has become a taboo, secondly, besides something that has been considered taboo from the start, it will make someone who holds the corpse also become a taboo.

Nevertheless Frazer. S. J (1886), states that the behavior and beliefs of the Polynesian people are only one of many superstitious systems among most people and have been considered to have a positive impact on human life in general. The aim is to enrich the complexity of cultural treasures that cover all aspects of life (religious, social, political, and moral and economic).

However, all forms of taboo or such taboos can be understood substantially in terms of local wisdom. By Hotibin (2013), local knowledge is a form of social and cultural values that exist in society, despite the diversity of the Indonesian nation in terms of ethnicity, race, culture, and others actually refer to the characteristics of each. At the same time, these characteristics generally have wisdom, which in the past became a source of value and inspiration in knitting and treading their lives.

History shows that each ethnic and tribal has its own local wisdom. For example (not to mention that there are all tribes and ethnicities in Indonesia), Bataknese are thick with openness, the Javanese are almost synonymous with refinement, the Madurese have high self-esteem, and the Chinese are known for their tenacity. More than that, each has a familiarity and friendliness with the natural environment that surrounds them. According to Putra (2008), local wisdom can be defined as a set of knowledge and practices, both derived from previous generations and from experience dealing with the environment and other communities belonging to a community in one place, which are used to solve well and effectively. the various problems and/or difficulties encountered.

Meanwhile, Ife (2002), states that local wisdom is values that are created, developed and maintained in local communities and because of their ability to survive and become a way of life for the community. Local wisdom includes various mechanisms and ways to behave, behave, and act as outlined in the social order. Local wisdom is all local intelligence that is transformed into creativity, work, and initiative so that people can be independent in various social climates that continue to change.

Copyrights, works, and intentions are also called culture. Culture is not a new term, but what is meant by culture is all the thoughts, behaviors, actions, and attitudes of life that people always do every day. In general, local wisdom is considered a way of life and knowledge as well as various life strategies in the form of activities carried out by local communities in responding to various problems in meeting their needs.

With these understandings, local wisdom is not just a traditional value or locality feature, but a traditional value that has the power to realize the expectations or values of the establishment which are also universally coveted by humans. The government and the community need to pay attention to their rights and participation as respect, protection, and fulfillment of their rights, including multidimensional problems and empowerment for the community.

This is in accordance with the legal basis of the 1945 Constitution article 28 I paragraph (3) that the cultural identity and rights of traditional communities are respected in line with the development of the times and civilization. Local wisdom here contains the meaning of 
noble values that apply in the life of the community, among others, to protect and manage the environment in a sustainable manner for the lives of the people in it and to keep it well maintained. .

To complete this description, the following are some of the main aspects related to local wisdom:

\section{Functions and Forms of Local Wisdom}

According to Nunung Unayah and Muslim Sabarisman (2016), talking about society and the environment, cannot escape the form of local wisdom that exists in the area and can be used as a value that is considered good for the lives of its people. According to Sirtha as quoted by Sartini (2004), explains that the forms of local wisdom that exist in the community can be in the form of: values, norms, beliefs, and special rules.

These various forms result in the function of local wisdom being varied as well. These functions include: 1) Local wisdom functions for the conservation and preservation of natural resources, 2) Local wisdom functions to develop human resources, 3) Functions as cultural and scientific development, and 4) Serves as advice, belief, literature, and taboos.

The same opinion, according to Sirtha in Hayati (2011) "Exploring Local Wisdom for Ajeg Bali" states that forms of local wisdom in society can be in the form of: values, norms, ethics, beliefs, customs, customary law, and special rules. . Because of its various forms and it lives in various cultures of society, its functions are various. In his writings "Balinese Behavior Patterns Referring to Tradition Elements", among others, provides information about several functions and meanings of local wisdom, namely:

1) Functioning for the conservation and preservation of natural resources,

2) Functioning for the development of human resources, for example relating to ceremonies. life cycle, the concept of kanda pat rate,

3) Functioning for the development of culture and science, for example at the Saraswati ceremony, belief, and worship at the Panji temple,

4) Functioning as advice, belief, literature, and taboos, for example in Ngaben ceremonies and Purification ancestral spirits,

5) Social meaning, for example communal/relative integration ceremony,

6) Ethical and moral meaning, for example in the agricultural cycle ceremony, and

7) Political meaning, for example languishing Ngangkuk ceremony, patron client power.

Local wisdom can be seen as a national identity, especially in the context of Indonesia which allows local wisdom to transform cross-culturally which in turn gives birth to national cultural values. Then Jim Ife (2002), from the aspect of its form, local wisdom can be grouped into several dimensions, namely:

first, local knowledge, in reality every community group always has local knowledge, especially those closely related to the natural environment in which they live and interact socially.

Second, local values, namely values that are created and mutually agreed upon by a community group for the sake of creating a harmonious, intimate relationship, having high social sensitivity,

third, local skills, namely the ability to survive (survival) of each member of the community will be realized if members people have skills that are preserved in their group life.

The form of local skills is closely related to the choice of people's way of life, for example, hunting, fishing, gathering and farming as well as household business (home industry), fourth, local resources, namely natural resources that are non-renewable and renewable. Utilization of local resources is in accordance with the needs and will not 
exploit arbitrarily, fifth, local decision-making mechanisms, this is closely related to the existence of customary structures with division of functions in regulating social relations, especially in the decision-making process in one-on-one tribes.

This people's house building is a residential building that was built and used by the majority of the community with reference to the traditional leader's house, as well as cultural/traditional heritage objects (artworks), such as a keris which has a function as an art symbol when viewed from the artistic aspect and is a symbol from the message of its creator and batik, as a craft that has high artistic value and has become part of Indonesian culture (especially Javanese), while local wisdom is intangible (not real), in the form of advice conveyed verbally and passed down from generation to generation. can be in the form of songs and hymns that contain traditional teaching values.

\section{Characteristics and Challenges of Local Wisdom}

In the discipline of anthropology, the term local genius is known. Local genius is a term that was first introduced by Quaritch Wales. Anthropologists have discussed at length this notion of local genius (see Ayatrohaedi, 1986). Among other things, Haryati Soebadio said that local genius is also a cultural identity, a national cultural identity/personality that causes the nation to be able to absorb and cultivate foreign cultures according to their own character and abilities (Ayatrohaedi, 1986). Meanwhile, Moendardjito (in Ayatrohaedi, 1986) said that the element of regional culture has the potential as a local genius because it has been tested for its ability to survive until now. The characteristics are: 1) able to withstand foreign cultures, 2) have the ability to accommodate elements of foreign cultures, 3) have the ability to integrate external cultural elements into the original culture, 4) have the ability to control, 5) be able to give direction to development culture.

\section{Social Dilemma}

Theoretically, a social dilemma is any situation where there is a role conflict or role dilemma (Soerjono Soekanto, 1985). According to Andi Suryadi (2019), theoretically in social science, there are two problems, namely social problems and social problems. Societal problems involve the analysis of various symptoms of people's lives, while social problems involve abnormal symptoms in society. Societal problems also focus on social and moral values, which are related to behavior that is immoral and against the law.

According to Jalaluddin Rakhmat (1999), the difference between das Sollen and das Sain. The problem can be at a social level or at an individual level. The pattern of solving these two problems is certainly different. Individual problems must be addressed individually, but if these individual problems cannot be resolved properly, they will turn into social problems, for example individual problems who are unemployed or not working, making the individual poor. This situation may be caused by the individual being lazy, or unskilled or something else. Of course, to solve this individual problem by changing the attitude from lazy to diligent, from not having self-skills changed by studying diligently to becoming skilled.

Solving social problems, in fact, requires social engineering by changing social institutions, social systems, and norms that previously existed in a society. The need to carry out a well-planned social change, not an individual one. In social reality, it turns out that the process of social change must begin with various discussions about social problems. This is seen as very important because the process of solving social problems to be achieved will fail. Desire to solve social problems, later being able to turn around will add to social problems. 
There are several social problems mentioned by social scientists as a source of change, namely: 1) poverty (poverty) a situation that involves large numbers of people, 2) very diverse and tiered crimes (crimes), the nature of which is blue callar crimes and white callar. crimes, 3) conflicts with very diverse backgrounds, such as racial, ethnic, sectarian, ideological, and so on.

\section{RESULTS AND DISCUSSION}

This section will present various views and opinions from the informants on how the real phenomenon of allergy to old values, pride in new values, which is then considered a social dilemma for Orang Ocu e, is viewed from the perspective of social anthropology. For this purpose, below will be presented in a structured manner the results of interviews with selected informants who are considered to know a lot about this phenomenon.

This understanding of the description of the identity of this group can actually be used as a basis for formulating various dilemmas that arise due to changes in the reference pattern of the Ocu people's values, including:

1) The emergence of a distance that is getting wider and sharper. with the informant Datuk Godang Syamsuar, who stated in the local language (the language of Orang Ocu as follows:

Ondek iyotio naang, ala ndo joawak adat gole. Baju ughang la wak pakai basamo-samo. Kan diboponyie komajuan dunioge nan manjadi pacocan ke adatge. Ndo tuode yie ndo mudo nompaah la samojie le. Dek iko juotie lamangano awak ge, nan lamo la batinggeen, nanbghu la bacubo-cubo dipakai-pakai. Bosuo manauw jo ehgek-ekhgek lamo ge, aghok ayu ujankantuwun, ayu didikulam babuang. Ikotie ponyokik nan diidok dek awak ngahng ocu. Tengok kingie yie anthgo nhgang tuo joghangmudoge landak basosuian le, bayiok cangho pikiu, cagho bakalokuan, cagho baundiong, sosodo nompaknyo. Lagak panya kingie moncao baundiong sauku, bakato mancai bulek kato, dek apodu, tutie dek la tapasang koin ughang lain, ndo adat kito ughang ocu gole nandiikukti (ndo congkoighi nan dituwuikle).

Meaning:

It must be justified that there has been a situation that is quite worrying related to the customs of our people (Ocu), namely a situation where the Ocu people are compared to wearing other people's clothes (using traditional values that are not their own). We have met a customary situation of Orang Ocu as the traditional expression itself, namely hoping for rain to fall from the sky, the water in the pot has been spilled. In today's reality, traditional values derived from ancestral values no longer seem to be the only reference in the behavior of Orang Ocu. It may be that this is more blamed on the younger generation of Orang Ocu, but it seems that slowly, consciously or unconsciously, they have also become models of behavior for all people. Another fact is that there has been a long gap or gap between the old and the young. This is due to different ways of behaving, such as ways of thinking, acting, and making decisions. This situation is allegedly caused by their own customary values which are no longer appreciated by the supporting community, namely Orang Ocu. 
2) What is the actual value reference of the Ocu people today, with the informant Ba'syirun Datuk Ghindotanalam, as follows:

Jomankini geyie landak buliojuo le bacakap nakjo condonan komua joule, lalawik aghigema. Laijolenyie lalawik aghige, nanlalamogeyie lakabatinggenm jie le, nompakah ndo nanmudo ndonantuo la sasamojie le noang. Kolo dipikiun yie sakik palotandeeh, tutio caghole yie pakuek jiele pakagho ugamogole. Ajauan adatkan baghasal daghi ajaighan agamo islamge, tutie caghole. Kolo ajauan adatge la bakatopiinma, dek apaodo ndak dapek solamanyolanndo sasamo waktengok jola kolakuan anak mudomudo ghang ocuge. Ndak anakmudojodo nanlatuopun lasamojie le. Tutie nyonyo deyen laiciekle tompek bagantuonle apoduyie ajaighan ugamo gotiele. Arotinyo ajaian adatge lajawuoma, bakkoto ghang tuotuo joman dolule, jalan dialiodek ngangnanlalu, labapakai pakaian ughang tontundokan sosuaide, tapaikan dibopontu nantajadi kinigeyie dinagonghi ghang ocuge.

Meaning:

Times have changed with new (modern) times, there is a tendency to shift to new values, both young and old without exception. Such a tendency will feel troubling, but there is one strength that must not fade, namely the strength of the practice of religious values. Are not the teachings contained in the traditional values actually sourced from the noble values of the Islamic religion. If you hope and rely on customary values, it is no longer possible. The change by abandoning these traditional values is analogous to the old saying, namely: The road was diverted by the past, and Orang Ocuhave been wearing other people's clothes that are not necessarily appropriate, that is (the traditional values).

3) Alternative possible settlements so that the community can get their money back, with the informant Bahardin Bahar, Datuk Ghindo Samanghajo, are as follows: Ga'ah indak adole nankan disobuk, manengok pacocan kocaubolau adatge, lakusuik sakusuiksakusuiknyieyie. Ghangnanmambo adat dukinige ndopadulin banaw dekghang anak ponakangele. Kolodibondionhgkan jawuobabedo joghang sumbartan. Nompak dekawak tangjawuoe laijuole adatge punyotuale. Kekbonjau awakge nyonyodeyen labanyak bauba, la dilangau, ndole pabadulinbanawle. Gogamnakaponaan ndole tasapole nyo banyak basikola tenggi-tenggi topi tutie ntadeapo ga'ah puongaio duyie ndocadak kolowk sondiongkan ke adatge. Jawuokughang tontang caghocagho iduikbakaumbakampuongge, misenyie piekpiek dagiong, manjolangsuaghang, ghaso mampatenggangkan, cukuiknanlainle. Kolountuok mampaeloknyoyie nyonyodeyen agak lapayage, topijan paputuiasoleyie, yotie mampakuek amalan agamogotele, sambie mampaelokjuo nanlakusuikdu. Kololaibasamosamoyie deyen piocayo baansuansum tontukan adopajojannyo.

Meaning:

It seems rather difficult to restore the situation when various violations of customary values have been carried out together. This means that if the violation of customary values has been carried out massively, it means that the value has changed to something that is permissible. However, we do not 
despair, there is still hope, namely by strengthening the practice with Orang Ocu towards Islamic religious values. In that process, the entire Ocu community made a commitment to return to using their traditional values as a reference for living with fellow Orang Ocu, as well as a reference for dealing with people outside Orang Ocu. The phenomenon that occurs in Orang Ocu is very different from the phenomenon in West Sumatra, even though it is only a vision from the outside. In Sumatra, perhaps customary values are still strong to be used as a reference for living together and in relationships with people outside. So by strengthening the practice of Islamic religious values, it is finally believed that it will also have a direct or indirect impact on efforts to improve customary values, especially in daily behavior.

4) Some aspects that make local wisdom still exist in society, with informant Manjaruddin (State Civil Apparatus), as follows:

Lailaijuole pakagho adatge nantogakluwile, topilabanayjuonan la megheng jotagendeng, laijuonanla tumbangbanaw. Arotinyonyie nanlatumbanglaijuo, nala tagendeng laijuo, ga'ah annlalalpuok taghondam mungkinga;hlaijuoyie. Nanlalapuok, nanlakusuik sakusuikkusiknyo lopenla umikkojidu. Kitokaji jielayie nanlai togakluwuijola nanwak citonkinige. Topikinige lapayamonaci manonan nilainilaiadekge nanjonio nantogakluweuidu, lakabujokolamma. nanlaileyie pakagho nilaiadekge tontangkawinmangawinge, mungkinyolai sobab laibabuekjuo tiokaghi bilolaighange nankawin tontubabuekjuole. Apodunoaang misieyie mangiuisiok, tubatando, samapi kaijabkobual koloituyotie laiyie. Ciekleyie kolobatganam batanamgoyie yotielai ndolai baubabaudo.Dekapoduyie ghangocugeyie kabonyakan kojonyobatanigela, bakobun mocammocam kobun. Jodiyie apaaponan manjodin babaghapo lainan adole sompaikinige baubuongjo kojokjo ghangocuge, nanlainga'ah lakolam ndakmanompakan ujuongiduongle latangolam.

Meaning:

Indeed, there may still be some values that can be classified as local wisdom of Orang Ocu. This is because the value of the wisdom of Orang Ocu can be categorized in several circumstances, for example, some have disappeared, some are in the process of being lost, and some are still carried out in various activities every day. Some forms of community activities of Orang Ocu which are then categorized as a form of local wisdom of Orang Ocu, such as carrying out activities to find out about the condition of an adult daughter to be made a husband or son-in-law by the male side's family, then an approach is carried out which is in the language of the local people. Ocu is called "nguisiok". It doesn't even end there, but includes the next steps. Why these values still exist, one of which is because these values are related to the marriage process which is always carried out by members of Orang Ocu. It seems that aspects of values that are not like that, consciously or unconsciously will face the process of disappearing in the daily practice of this society. 


\section{Discussion}

Understanding the substance of all the data stated in the discussion above, it can be concluded that the phenomenon of allergy to old values, pride in new values, which is then considered a social dilemma for Orang Ocu, from the perspective of social anthropology, actually exists and is ongoing. As Orang Ocu's traditional expression "aghok ayu jatuo daghi langik, ayu dikulam babuangkan", which means expecting rain to fall from the water in the jar, is in accordance with the situation and the respect for customary values is so low by members of the community who support the custom. Such a clear picture of the analogy of the low appreciation of members of Orang Ocutowards traditional values in the form of low local wisdom, as expressed in the adat petitih petatah, namely "jalan dialio dek ughang nanlalu", meaning that the way has been changed by other parties who have just arrived in the middle. society, but is able to change the appreciation of the old values left behind to accept new values. This analogy is of course confronted with various advances in science and technology, as well as forms of cultural behavior that are seen and watched by the younger generation of Orang Ocu, consciously or unconsciously practiced in the daily life of Orang Ocu.

In this context, the choice of several phenomena that are closely related to the social reality of Orang Ocu, which then relates to how they appreciate their own cultural values. This means that the lower the appreciation of their cultural values, of course it can be used as a basis for saying that they no longer live in an atmosphere of their own cultural values but have made other people's cultural values as a reference in their lives. The following aspects relate to their existence (Orang Ocu) and their cultural values, including:

a) related to the appearance of the distance that is getting wider and sharper, it turns out that this is indeed the case. As stated by the informant that there has been a fairly worrying condition related to the customs of our people (Ocu), namely a situation where Orang Ocu are compared to wearing other people's clothes (using traditional values that are not their own traditional values). We have met a customary situation of Orang Ocu as the traditional expression itself, namely hoping for rain to fall from the sky, the water in the pot has been spilled.

b) what is the actual reference to the values of Orang Ocu today, times have changed to a new (modern) era, there is a tendency to shift to new values, both young and old, without exception. Such a tendency will feel troubling, but there is one strength that must not fade, namely the strength of the practice of religious values.

c) Alternative solutions that might be done so that the community gets its value reference back, it seems rather difficult to restore the situation when various violations of customary values have been carried out together. This means that if the violation of customary values has been carried out massively, it means that the value has changed to something that is permissible. However, we do not despair, there is still hope, namely by strengthening the practice with Orang Ocutowards Islamic religious values. In that process, the entire Ocu community made a commitment to return to using their traditional values as a reference for living with fellow Orang Ocu, as well as a reference for dealing with people outside the Ocu people.

d) Some aspects that make local wisdom still exist in society. Indeed, there may still be some values that can be grouped as local wisdom of Orang Ocu. This is because the value of the wisdom of Orang Ocu can be categorized in several circumstances, for example, some have disappeared, some are in the process of being lost, and some are still carried out 
in various activities every day. Some forms of community activities of Orang Ocu which are then categorized as a form of local wisdom of Orang Ocu, such as conducting activities to find out about the condition of an adult daughter to be made a husband or son-in-law by the family of the male party, an approach is taken.

\section{CONCLUSION}

The phenomenon of allergy to old values, pride in new values, which is then considered as a social dilemma for Orang Ocu, from the perspective of social anthropology, has really existed and is ongoing. In principle, this allergy has caused concern for various parties, in this case the traditional stakeholders, intellectuals such as the State Civil Apparatus (ASN), even Orang Ocu who live in various regions. This allergy phenomenon is proportionally more shown by the behavior forms of young people compared to older people.

The impact of the increasingly wide gap between these two groups, consciously or unconsciously, will certainly lower the quality of protection, attention and teaching from the old to the young. The lack of it will provide opportunities for young people who are so wild to get new information from various sources. This variety of information will encourage young people to practice it in the process of daily life. In the end, they are more used to (enjoy) the new values, by showing allergies to old values that are not necessarily in accordance with the values of their original culture.

\section{REFERENCES}

Ahmad, H (2012). Makalah Kearifan Lokal di Muria, http://krewengcool.blogspot. co.id/2012/06/makalah-kearifan-lokaldi-muria.html. accessed Januari 14 2016, Dalam Nunung Unayah dan Muslim Sabarisman 2016. Identification Of Local Wisdom In The Empowerment Isolated Traditional Community, Sosio Informa Vol. 2, No. 01. Kesejahteraan Sosial.

Andi Suryadi. (2019). Problematika Sosial, Pemanfaatan Lahan Pada Lokasi Pembangunan Tanggul Pantai Di Teluk Jakarta Dan Alternatif Penyelesaiannya, Prsiding Seminar Antara Bangsa Ke-8 Arkeologi, Sejarah, Bahasa Dan Budaya Di Alam Melayu (Jilid 1), Ancasa Residences, Port Dikcson, Malaysia.

Ayatrohaedi. (1986). Kepribadian Budaya Bangsa (local Genius), Pustaka Jaya, Jakarta, Dalam Nunung Unayah dan Muslim Sabarisman 2016. Identification Of Local Wisdom In The Empowerment Isolated Traditional Community, Sosio Informa Vol. 2, No. 01. Kesejahteraan Sosial.

Jim Ife. (2002). Community Development. Community Based Alternative in a of Globalization. Australia: Longman is an Imprint of Paperson Education. Marfua'ah, $R$ (2014). Laporan Identifikasi, Dlm. Nunung Unayah, Muslim Sabarisman. 2016. Pusat Penelitian dan Pengembangan Kesejahteraan Sosial, Kementerian Sosial RI

Bakti Setiawan. (2006). Pembangunan Berkelanjutan dan Kearifan Lingkungan. Dari Ide Ke Gerakan, PPLH Regional Jawa, Kementerian Negara Lingkungan Hidup RI, Yogyakarta.

Frazer. S. J. (1886). Radcliffe-Brown. A. R. 1952. Struktur Dan Fungsi Dalam Masyarakat Primitif. Dewan Bahasa Dan Pustaka, Kementrian Pelajaran Malaysia, Kuala Lumpur. 1980.

Hayati, S. et al. (2011). Model Penanaman Nilai-Nilai Kearifan Lokal pada Masyarakat Sunda dalam Membentu Perilaku Lingkungan Bertanggung Jawab. Bandung: UPI Bandung. 
Hotibin. (2013). Sekilas tentang Kearifan Lokal Masyarakat, Dalam Sosio Informa Vol. 2, No. 01. Kesejahteraan Sosial, Dalam Nunung Unayah dan Muslim Sabarisman 2016. Identification Of Local Wisdom In The Empowerment Isolated Traditional Community, Sosio Informa Vol. 2, No. 01, Kesejahteraan Sosial.

Francis Wahono. (2005). Pangan, Kearifan Lokal dan Keanekaragaman Hayati, Penerbit Cindelaras Pustaka Rakyat Cerdas, Yogyakarta Gunggung Seno Aji, 2003. http://kejawen.co.cc/pranoto-mongso-aliran-musim-asli-jawa. Kejawen: Pandangan Hidup dan Falsafah Kehidupan Orang Jawa, accessed January 26 2009. (23.00 PM)

Jalaluddin Rakhmat. (1999). Rekayasa Sosial (Revormasi, Revolusi, Atau Manusia Besar), PT. Remaja Rosdakarya, Bandung.

Izikowitz Karl G. (1963). in Barth, F. 1969. Ethnic Groups and Boundaries. (pnyt) Nining. L. Soesilo. 1988 (pnyt). Kelompok Etnik dan Batasannya, Tatanan Sosial dari Perbedaan Kebudayaan. Jakarta: Universiti Indonesia Press.

Moendardjito (in Ayatrohaedi, 1986). Kepribadian Budaya Bangsa (local Genius), Pustaka Jaya, Jakarta, Dalam Nunung Unayah dan Muslim Sabarisman 2016. Identification Of Local Wisdom In The Empowerment Isolated Traditional Community, Sosio Informa Vol. 2, No. 0. Kesejahteraan Sosial.

Nunung Unayah dan Muslim Sabarisman 2016. Identification Of Local Wisdom In The Empowerment Isolated Traditional Community, Sosio Informa Vol. 2, No. 01,. Kesejahteraan Sosial.

Purba, J. (2014). Variabel Inventarisasi Kearifan Lokal Dalam PPLH, Bahan Materi Pertemuan Penyempurnaan Instrumen Inventarisasi Kearifan Lokal. Jakarta: Kemensos, Dalam Nunung Unayah dan Muslim Sabarisman 2016. Identification Of Local Wisdom In The Empowerment Isolated Traditional Community, Sosio Informa Vol. 2, No. 01. Kesejahteraan Sosial.

Putra, A, Heddy, S. (2002). Tanda, Simbol, Budaya, dan Ilmu Budaya. Makalah dalam Ceramah Kebudayaan, Fakultas Ilmu Budaya. Yogyakarta: UGM, Dalam Nunung Unayah dan Muslim Sabarisman 2016. Identification Of Local Wisdom In The Empowerment Isolated Traditional Community, Sosio Informa Vol. 2, No. 01,. Kesejahteraan Sosial.

Radcliffe-Brown. A. R. (1952). Struktur Dan Fungsi Dalam Masyarakat Primitif. Dewan Bahasa Dan Pustaka, Kementrian Pelajaran Malaysia, Kuala Lumpur. 1980.

Sartini. (2004). Menggali Kearifan Lokal Nusantara Sebuah Kajian Filsafat, Dalam https://repository.ugm.ac.id/273938/1/JF\%202004\%20Menggali\%20Kearifan\%20Lokal $\% 20$ Nusantara\%20sebuah\%20Kajian\%20Filsafat.pdf.

Soerjono Soekanto. (1985). Sosiologi Suatu Pengantar, PT. RajaGrafindo Persada. Jakarta

Soerjani, M., et al. (1987). Lingkungan: Sumberdaya Alam Dan Kependudukan Dalam Pembangunan, UI Press, Jakarta. Dalam Dendi Sutarto, 2009, Kearifan Budaya Lokal Dalam Pengutan Tradisi Malemang Di Tengah Masyarakat Modernisasi Di Sungai Keruh Musi Banyuasin Sumatera Selatan.

Syafrizal. (2004). Identitas dan Batas-Batas Etnik Orang Di Kabupaten Kampar Propinsi Riau, thesis.

Syafrizal. (2017). Perubahan S0siobudaya, sosioekonomi Orang Ocu Kesan Program Transmigrasi Di Indonesia, Universitas Kebangsaan Malaysia, Dissertation.

Jim Ife. (2002). Community Development. Community Based Alternative in a of Globalization. Australia: Longman is an Imprint of Paperson Education. Marfua'ah, $R$ (2014). Laporan Identifikasi, Dlm. Nunung Unayah, Muslim Sabarisman. 2016. Pusat Penelitian dan Pengembangan Kesejahteraan Sosial, Kementerian Sosial RI. 
Sztompka, Piotr. (1993). The Sociology of Social Change, (terj.) Alimandan. 2004. Sosiologi Perubahan Sosial. Perpustakaan Nasional: Katalog Dalm Penerbitan (KDT), Jakarta, Prenada Media.

Wahono, F. (2005). Pangan, Kearifan Lokal dan Keanekaragaman Hayati. Yogyakarta: Penerbit Cindelaras Pustaka Rakyat Cerda, Dalam Nunung Unayah dan Muslim Sabarisman 2016. Identification Of Local Wisdom In The Empowerment Isolated Traditional Community, Sosio Informa Vol. 2, No. 01, Januari - April, Tahun 2016. Kesejahteraan Sosial. 